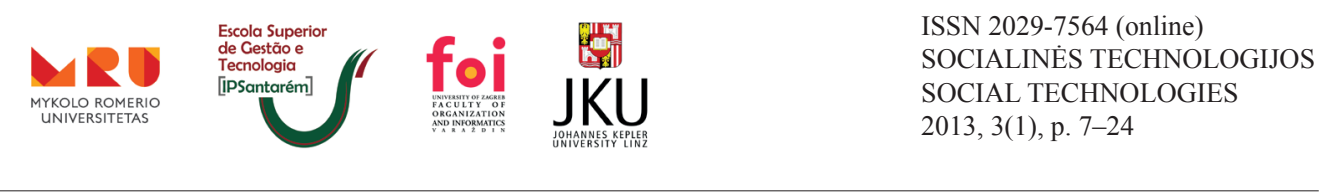

\title{
HYBRID RECOMMENDER STRATEGY IN LEARNING: AN EXPERIMENTAL INVESTIGATION
}

\author{
Filipe Montez Coelho Madeira \\ Polytechnic Institute of Santarém, Portugal, filipe.madeira@esg.ipsantarem.pt \\ Salvador Abreu \\ University of Évora, Portugal, spa@di.uevora.pt \\ Rui Filipe Cerqueira Quaresma \\ CEFAGE-University of Évora, Portugal, quaresma@uevora.pt \\ doi:10.13165/ST-13-3-1-01
}

\section{Abstract}

Purpose - finding ways of improving learning in a formal higher education context.

Design/methodology/approach_in the proposed model we will consider extending traditional content management systems, giving learners the possibility to add new materials and to rate them, and a hybrid strategy that combines technical recommendations with some profile-based filtering to offer adaptive and suitable sequencing learning content to learners.

Findings - the experiment shows that our recommendation techniques are able to reflect the learners' interests.

Research limitations/implications - it's necessary to demonstrate the contributions of these kinds of solutions to the learners' success.

Practical implications - theoretical and practical framework for future research in the field was developed. 
Originality/Value — the main contributions are the extended Learning Management System and the hybrid Recommender System, which implements a new proposal to evaluate learners' similarities.

Keywords: recommender strategy, personalized recommender systems, collaborative filtering, collaborative formal learning, sequencing, learner profile, technology enhanced learning.

Research type: research paper.

\section{Introduction}

In the Internet, identifying suitable learning resources from a potentially overwhelming variety of choices became a critical service. Different learners with different characteristics, skills, capacities and goals, seek for the most suitable learning activities and materials. Different contents and adaptive sequencing on learning activities are some of the requirements for this to happen.

The main topic of this paper is to find ways to improve learning in a formal Higher Education context. In the typical environment, the teacher publishes or suggests content which supports learners in a given course, as supplements of classroom training. Generally, these materials are pre-stored and not changeable. Such contents are typically published in a Learning Management System (LMS), such as the Moodle platform, or in sites created and maintained on the web by the teachers themselves. Normally, these scenarios include a specific group of students (class) and a given period of time (semester or school year). Contents reutilization often needs replication and its update requires new edition and new submission by the teachers. Usually, in LMSs only teachers can publish contents (in typical formal education courses).

In the proposed model we will consider two different systems. In the first one, the extended content management system, learners can select pre-existing materials and add new materials to a web-based platform. They are also required to evaluate and point out how much time it took to study those materials. The second system provides a hybrid strategy that combines technical recommendations with some profile-based filtering to offer adaptive and suitable sequencing learning contents to learners, in order to be able to improve personalization of learner's learning path and also adding diversity to the learner ways of study; that is, to recommend the most interesting or relevant Learning Objects (LOs) to each learner.

The proposed system makes individualized recommendations of LOs for learners, and has been implemented in the Moodle LMS. The present paper describes an experimental investigation of this pilot system in one class of a real formal higher education course. In this paper, the term "LO" is used instead of content term, because we considered it as a broad concept, close to that of the learning activity, and may represent a document, a link to some resource hosted on the web, a questionnaire, an exercise file, etc. 


\section{Related Work}

In recent years, digital interaction between learners and between learners and teachers has dramatically increased, especially because of the Internet. The behaviour and contributions of each agent in this learning process can improve and change the learning contexts. Iglesias et al. (2004) refer that social interaction may influence the adaptive sequencing of learning activities, considering the interactions within a group. Koper (2005) purposes one system that suggests the next activities based on successfully completed (by other students) activities. Gutiérrez and Pardo (2007) suggest the use of annotations, indicating how many students have already done and how many have successfully completed a given activity.

One kind of social interaction can be implemented using Recommender Systems (RSs). There are many RSs with different types designed to support learning activities. Manouselis et al. (2011) provide an introduction to RSs for Technology Enhanced Learning (TEL) settings considering the particularities of this application domain. The main purpose of such systems is to filter information which may interest or help each learner on his choice or selection. The Altered Vista system (Walker et al., 2004) recommends web addresses based on teacher and learner evaluations. Rafaeli et al. (2004) propose one collaborative filtering system where users can select the users from whom they want to accept recommendations. Manouselis et al. (2010) describe a case of developing a learning resources collaborative filtering service for an online community of teachers in Europe. Some proposals have been developed using multiple criteria to perform collaborative filtering, like Manouselis et al. (2007) did. Some authors have proposed the use of hybrid strategies, arguing that they produce recommendations more reliable when compared with the single use of one technique (cf. Soboroff et al., 1999; Pazzani, 1999; Melville et al., 2002), and some hybrid systems have also been developed (Tang and McCalla, 2005; Drachsler et al., 2008; Zapata et al., 2011). Another interesting work is developed by Drachsler et al. (2009), who compared the recommender system's applicability in informal versus formal education.

Herlocker et al. (2004) review some key decisions in evaluating collaborative filtering RSs. Some proposals that have been implemented have also been evaluated using different techniques, like surveys (Zapata et al., 2011), metrics (Liang et al., 2006), or both surveys and metrics (Manouselis et al., 2010), like we did.

Our hybrid RS differs from previous works essentially in the way we implement the similarity of learners and our collaborative filtering approach. One additional and original idea from our work resides in the possibility for learners to include additional LOs.

The remainder of this paper is organized as follows: in the next section we will present the overall system architecture, the details of each subsystem and techniques we are applying for the second subsystem to present recommendations. In the following section, we will describe a running example. After this section, we will present detailed information about the experimentation procedure and some of its results. We'll conclude 
this paper with some considerations, discussing limitations and improvements needed for the proposed system, as well as giving some directions for future work.

\section{A Hybrid Recommender Strategy on an Expanded Content Manager}

Our proposed system includes two subsystems: one which allows learners to add new LOs and a second subsystem that recommends LOs to learners (see Fig. 1).

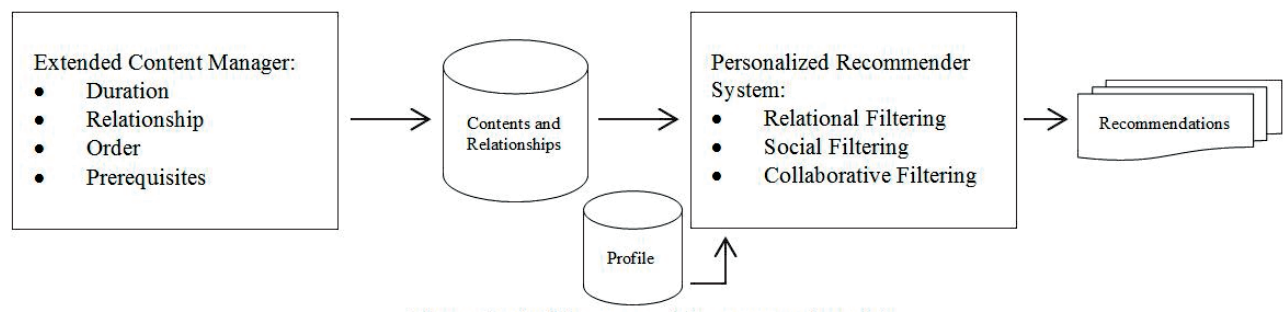

Fig. 1. Architecture of the proposed model

\subsection{Extended Content Manager}

The extended content management system has an innovative process with several steps, which begins with the submission of one new LO. After that, the next steps include the definition of its sequence order, its prerequisites (if applied), its relationship with other LO, validation and final publication (see Fig. 2). All LOs from the same topic must have the same order number and relationships are only established between LOs which have the same topic. For each topic, one LO must be classified as "base" (a main LO about a topic), and the others can be classified as "upgrade," "similar" or "supplementary". This field facilitates the identification and selection of LOs associated with a determined topic. Prerequisites are associated with topics in order to force a learner studying a necessary topic before. Each topic has only one topic as prerequisite thus all LOs of the same topic share the same prerequisite.

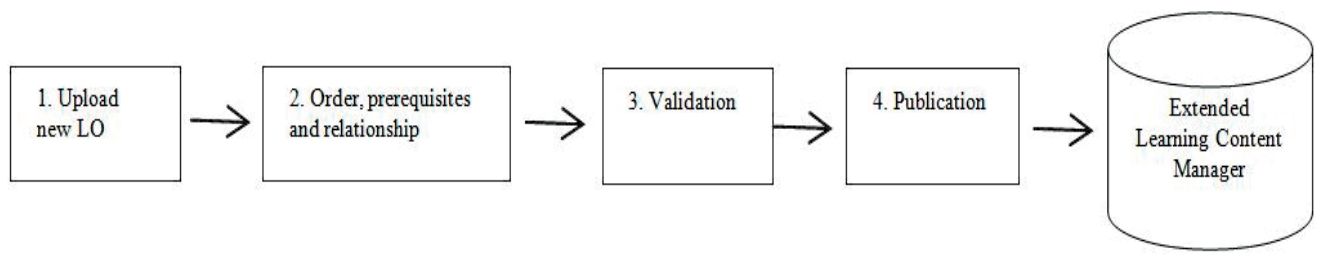

Fig. 2. Steps for publication of LOs 
All of these four steps correspond to features accessible to teachers. Learners only have access to the features of step 1. They can also establish relationships of LOs, but learners aren't able to define the order of LOs, nor indicate any prerequisites. The person that publishes the LO may also indicate an estimated time needed to study it. Only after approval do the new LOs become available for publication and subsequent access by all learners.

\subsection{Hybrid Recommender System for LOs}

In this proposal, one of our central ideas, in which we believe in, is that students with the same goals and with similar enrolments in formal courses can benefit from LOs assessments made by learners that already have completed the same courses and have studied the same LOs. The recommender support subsystem aims to assist learners during each step, suggesting one suitable ordered list of LOs, by decreasing order of relevance. To accomplish this goal, we propose a hybrid strategy with some different techniques, applicable in cascade, each one refining the received list of recommendations (see Fig. 3). At a final stage we try to predict the satisfaction level of the list of resulting LOs. It can be formulated as follows:

$$
\mathrm{u}_{\mathrm{ac}}: \mathrm{A} \times \mathrm{C} \rightarrow \mathrm{R}
$$

where:

A is the set of students enrolled in the course;

$\mathrm{C}$ is the set of LOs that can be recommended;

$\mathrm{R}$ is an ordered set of recommendations and

$\mathrm{u}_{\mathrm{ac}}$ is the utility function that predicts the LO's classification to the learner.

Recommendation techniques are based on the interests of learners, defined in their profile. In a learner profile we have considered the minimum desired satisfaction level (scale 1 to 5), the maximum duration of the study for each LO, the sequence length (i.e. what are the previously selected LOs and in what order) and the desired minimum assessment. These values should be explicitly added by each learner to their profiles. Note that values on the profile of each learner correspond to their interests, and not necessarily reflect their behaviour. For example, one learner may have an average duration of study of 30 minutes for each LO, but if he has availability to take up more time with each one, he can set in his profile a higher duration than his average. 


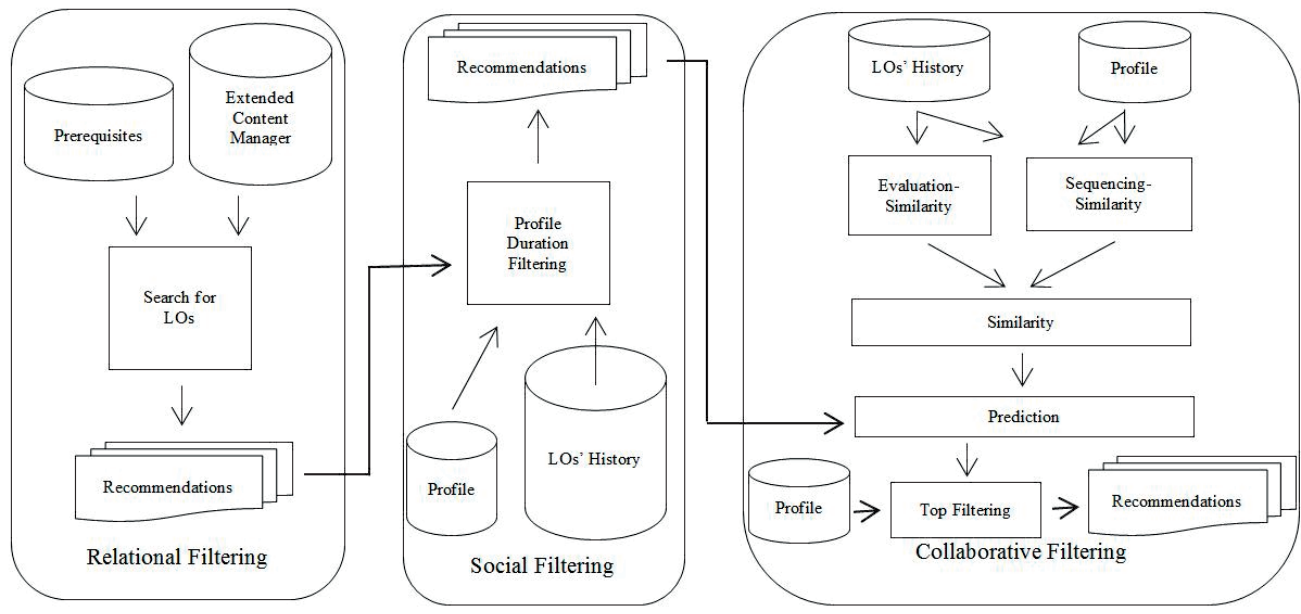

Fig. 3. Hybrid recommendation strategy

Before asking for a new recommendation, it is checked whether there isn't any LO to be finalized by the active learner. If this condition is verified, the first technique (relational filtering) is applied to determine which LOs the learner may choose. This process excludes LOs that have already been selected by the active learner and those LOs that have prerequisites not yet attended (i.e. they need other LOs to be done firstly).

In phase 2, if the learner has defined, on his profile, the maximum duration of study time he is prepared to spend in a single LO, the list obtained from phase 1 is revised, taking in account the study time indicated by the other students for each LO in the list (social filtering). This average time calculation includes the suggested duration indicated by the LO's publisher (teacher or learner). This solution solves the cold-start problem when one LO has no selections. The result's list includes only the LOs with an average time shorter than or equal to the time defined in the profile of the active learner. If the learner does not define any minimum time in his profile, it is maintained that the same list has resulted from stage one.

For each LO, c, this average time $\overline{\mathrm{d}_{\mathrm{c}}}$ is obtained by the following formulation:

$$
\overline{\mathrm{d}_{\mathrm{c}}}=\frac{\sum_{\mathrm{a} \in \mathrm{A}} \mathrm{d}_{\mathrm{a}, \mathrm{c}}}{\mathrm{A}}
$$

where:

$\mathrm{A}$ is the set of all the learners that have selected LO $\mathrm{c}$ and have defined its value for the duration field, plus its publisher (learner or teacher);

$\mathrm{d}_{\mathrm{a}, \mathrm{c}}$ is the duration of LO $\mathrm{c}$ defined by learner a or by its publisher.

The next step (3) begins with the calculation of the similarity between learners (defined between a minimum of 0 and a maximum of 1 ). This similarity is calculated from two metrics. The first metric considers the average grade achieved by each learner in the 
active course and the grade value defined in the active learner's profile. For colleagues with a grade greater than or equal to that value, the maximum value of similarity (1) is assigned. The complete formulation is:

$$
\operatorname{sim}_{a_{i}, a_{j}}=\left\{\begin{array}{cr}
1-\frac{\left(G_{i}-g_{j}\right)}{G_{i}} & g_{j}<G_{i} \\
1 & g_{j} \geq G_{i}
\end{array}\right.
$$

where:

$\operatorname{sim}^{\mathrm{g}}{ }_{\mathrm{a}_{\mathrm{i}}, \mathrm{a}_{\mathrm{j}}}$ is the metric that evaluates the grade-similarity between learners $\mathrm{a}_{\mathrm{i}}$ and $\mathrm{a}_{\mathrm{j}}$; $\mathrm{G}_{\mathrm{i}}$ is the grade defined in the active learner $\mathrm{a}_{\mathrm{i}}$ profile and

$g_{j}$ is the grade achieved by the learner $a_{j}$.

The second measure considers the size of the sequence defined in the active learner's profile. We propose that the selection of the same object and at the same order, in the past, by other learners means that they have more similarities among themselves, so future choices should consider this proximity. The value defined in the profile of each student sets the sequence length for the latest LOs studied. Learners who selected the same LOs in exactly the same order (even if in different positions), will have maximum similarity. For new students, who have not yet selected any LO, this metric is not calculated. This measure is calculated using expression 4 :

$$
\operatorname{sim}_{a_{i}, a_{j}}=\frac{\sum_{k=1}^{n} \exists c_{k, j}+\sum_{k=1}^{n-1} \Delta c_{k, j}}{(2 * n)-1}
$$

where: $\mathrm{a}_{\mathrm{i}}$ and $\mathrm{a}_{\mathrm{j}}$;

$\operatorname{sim}^{s}{ }_{a_{i}, a_{j}}$ is the metric that evaluates the sequencing-similarity between the learners

$n$ is the sequence length defined in the active learner $a_{i}$ profile, or the number of LOs that he has already selected, if this number is less than $n$.

$$
\Delta\left(c_{k, j}\right)=\left\{\begin{array}{lr}
1 & \operatorname{pos}_{j}\left(c_{k+1, i}\right)-\operatorname{pos}_{j}\left(c_{k, i}\right)=1 \\
0 & \text { others }
\end{array}\right.
$$

where:

$\Delta\left(c_{k j}\right)$ is the difference between the positions of the sequence order for the several pairs of LOs that the active learner $a_{i}$ has selected, considering the learner $a_{j}$ learning path.

$$
\exists c_{k, j}=\left\{\begin{array}{lr}
1 & \text { if } c_{k} \text { was selected by } a_{j} \\
0 & \text { others }
\end{array}\right.
$$

where:

$\exists c_{k, j}$ represents the selection of $L O c_{k}$ for learner $a_{j}$. 
The final learner similarity between two learners is obtained by the arithmetic average of the two metrics. If one metric value is 0 , then the value of the other metric will be the only one to be considered.

Finally, to complete this stage of collaborative filtering, for all LOs that belong to the previous output list we will predict the expected satisfaction value of the active learner. To calculate these prediction values we consider usual formulations from memory-based collaborative filtering algorithms (Breese et al. 1998):

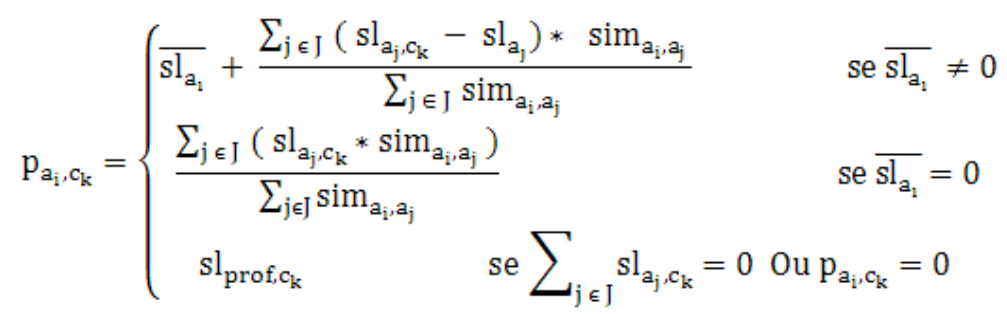

Where:

$\mathrm{p}_{\mathrm{a}_{\mathrm{i}}, c_{\mathrm{k}}}$ is the prediction of the satisfaction level for $\mathrm{LO}_{\mathrm{k}}$ to the active learner $\mathrm{a}_{\mathrm{i}}$; $\operatorname{sim}_{\mathrm{a}_{\mathrm{i}}, \mathrm{a}_{\mathrm{j}}}$ is the metric that evaluates the global similarity between learners $\mathrm{a}_{\mathrm{i}}$ and $\mathrm{a}_{\mathrm{j}}$;

$\mathrm{sl}_{\mathrm{a}_{\mathrm{j}}, \mathrm{c}_{\mathrm{k}}}$ is the satisfaction level explicitly defined by learner $\mathrm{a}_{\mathrm{j}}$ for $\mathrm{LO} \mathrm{c}_{\mathrm{k}}$;

$\underline{\mathrm{sl}_{\mathrm{a}_{1}}}$ is the average satisfaction level considering all selected LOs by learner $\mathrm{a}_{\mathrm{i}}$;

$\frac{\mathrm{sl}_{\mathrm{a}_{1}}}{\mathrm{a}_{1}}$ is the same concept but for learner $\mathrm{a}_{\mathrm{j}}$.

The last formulation (7) provides some solutions for the cold-start problem. When new students enrol in a course, there are neither selections, nor LO evaluations. The same situation occurs when a new LO is imported. In these cases, or if the prediction value is zero, the final prediction value for the satisfaction level of a given LO is the default value assigned by the teacher.

The final list of LO recommendations is ordered by the prediction values obtained, in decreasing order, and filtered based on the minimum desired level of satisfaction indicated by the active learner. Only LOs with a value superior or equal to the one indicated in the learner profile will be presented to him. From this final list, each learner can select one or more LOs, not necessarily the highest ones on the list.

\section{Running Example}

In this section, we introduce a simple running example to better illustrate a typical flow of the proposed system. Suppose there are four learners $\left(a_{1} \ldots a_{4} a_{4}\right)$ and six LOs $\left(c_{1} \ldots c_{6}\right)$. Some LOs have been selected by some learners (sequence column). Learners have defined some of the fields in their profiles, and some have an average grade (grade column) calculated from topics that they had completed before. Each learner registered the necessary study time (d) and satisfaction level (sl) for each LO that they have already done. This example is shown in Table 1. 
Table 1. List of selected LOs and learner profiles

\begin{tabular}{|c|c|c|c|c|c|c|c|c|}
\hline \multirow{2}{*}{ Learner (profile) } & \multicolumn{6}{|c|}{ LO's } & \multirow{2}{*}{ Sequence } & \multirow{2}{*}{ Grade } \\
\hline & $\begin{array}{c}\mathrm{C}_{1} \\
(\mathrm{~d}=50, \mathrm{sl}=3)\end{array}$ & $\begin{array}{c}\mathrm{c}_{2} \\
(\mathrm{~d}=30, \mathrm{sl}=4)\end{array}$ & $\begin{array}{c}\mathrm{c}_{3} \\
(\mathrm{~d}=60, \mathrm{sl}=4)\end{array}$ & $\begin{array}{c}\mathrm{C}_{4} \\
(\mathrm{~d}=40, \mathrm{sl}=4)\end{array}$ & $\begin{array}{c}\mathrm{C}_{5} \\
(\mathrm{~d}=50, \mathrm{sl}=4)\end{array}$ & $\begin{array}{c}\mathrm{c}_{6} \\
(\mathrm{~d}=50, \mathrm{sl}=5)\end{array}$ & & \\
\hline $\begin{array}{c}\mathrm{a}_{1} \\
(\mathrm{~d}=55, \mathrm{sl}=4, \mathrm{~g}=17 \\
\mathrm{n}=3)\end{array}$ & $\begin{array}{c}\mathrm{d}=50 \\
\mathrm{sl}=4\end{array}$ & $\begin{array}{l}\mathrm{d}=20 \\
\mathrm{sl}=5\end{array}$ & & $\begin{array}{c}\mathrm{d}=40 \\
\mathrm{sl}=3\end{array}$ & & & $\mathrm{c}_{1}, \mathrm{c}_{2}, \mathrm{c}_{4}$ & 14 \\
\hline $\begin{array}{c}\mathrm{a}_{2} \\
(\mathrm{~d}=50, \mathrm{sl}=4, \mathrm{~g}=14, \\
\mathrm{n}=2)\end{array}$ & $\begin{array}{c}\mathrm{d}=40 \\
\mathrm{sl}=3\end{array}$ & $\begin{array}{c}\mathrm{d}=40 \\
\mathrm{sl}=3\end{array}$ & & $\begin{array}{c}\mathrm{d}=40 \\
\mathrm{~s} \mathrm{l}=3\end{array}$ & $\begin{array}{c}\mathrm{d}=60 \\
\mathrm{sl}=3\end{array}$ & & $\mathrm{c}_{5}, \mathrm{c}_{1}, \mathrm{c}_{2}, \mathrm{c}_{4}$ & 13 \\
\hline $\begin{array}{c}\mathrm{a}_{3} \\
(\mathrm{~d}=30, \mathrm{sl}=4, \mathrm{~g}=15)\end{array}$ & $\begin{array}{c}\mathrm{d}=60 \\
\mathrm{sl}=3\end{array}$ & & & $\begin{array}{c}\mathrm{d}=40 \\
\mathrm{sl}=3\end{array}$ & $\begin{array}{c}\mathrm{d}=60 \\
\mathrm{sl}=5\end{array}$ & & $\mathrm{c}_{4}, \mathrm{c}_{1,} \mathrm{c}_{5}$ & 15 \\
\hline$\underset{(\mathrm{d}=40, \mathrm{sl}=4, \mathrm{~g}=14)}{\mathrm{a}_{4}}$ & & $\begin{array}{c}\mathrm{d}=60 \\
\mathrm{sl}=3\end{array}$ & & $\begin{array}{c}\mathrm{d}=40, \\
\mathrm{sl}=3\end{array}$ & $\begin{array}{c}\mathrm{d}=40, \\
\mathrm{sl}=5\end{array}$ & $\begin{array}{c}\mathrm{d}=45 \\
\mathrm{sl}=4\end{array}$ & $\mathrm{c}_{5}, \mathrm{c}_{6}, \mathrm{c}_{2}, \mathrm{c}_{4}$ & \\
\hline
\end{tabular}

After step 1, where relational filtering occurs, the resulting list of LOs for learner $\mathrm{a}_{1}$ is formed by the following set of LOs (not yet been selected by him): $\left\{\mathrm{C}_{3}, \mathrm{C}_{5}, \mathrm{c}_{6}\right\}$.

In the next step, called social filtering, the study time of other students is used to calculate the average time for each LO. This value is compared with time defined in the learners' profile to decide if it will be maintained or removed from list of recommendations. Thus, for $\mathrm{LO} \mathrm{C}_{5}$, which has an estimated duration assigned by the teacher of 50 minutes, the average duration is 52.5 (less than profile value of 55 for learner $\mathrm{a}_{1}$, so this $\mathrm{LO}$ will remain in the list). Because $\mathrm{LO} \mathrm{C}_{3}$ has not yet been selected, its default value (60 minutes) will be considered. Hence, this $\mathrm{LO}$ will be removed from the list of recommendations for the same learner $a_{1}$. At the end of this step, the list is formed by LOs $\left\{c_{5}, c_{6}\right\}$.

The calculation of the grade-similarity is the first step of the collaborative filtering phase. Considering the data of Table 1, $\operatorname{sim}^{\mathrm{g}}{ }_{\mathrm{a}_{1}, \mathrm{a}_{2}}=0.76([1-(17-13) / 17]) ; \operatorname{sim}_{\mathrm{a}_{2, \mathrm{a}_{1}}}^{\mathrm{g}}=1$ (the grade achieved by learner $a_{1}$ is equal to that defined in the profile of learner $a_{2}$, i.e. 14 values); and $\operatorname{sim}_{\mathrm{a}_{1}, \mathrm{a}_{3}}=0.88$ and $\operatorname{sim}_{\mathrm{a}_{1}, \mathrm{a}_{4}}$ can't be calculated because there is no grade defined for learner $a_{4}$.

After that, it follows the calculation of sequence-similarity. Its value is 1 for $\operatorname{sim}_{a_{1}, a_{2}}$ , because learner $\mathrm{a}_{2}$ has done the same sequence of $\mathrm{LOs}$ (length equal to 3 ) that learner $\mathrm{a}_{1} \operatorname{did}\left(\mathrm{c}_{1}, \mathrm{c}_{2}, \mathrm{c}_{4}\right) ; \operatorname{sim}^{\mathrm{s}} \mathrm{a}_{1, \mathrm{a}_{3}}=\frac{2+0}{5}=0.4$ and $\operatorname{sim}^{\mathrm{s}} \mathrm{a}_{1, \mathrm{a}_{4}}=\frac{2+1}{5}=0.6$.

As already mentioned, global similarity metric is obtained by the arithmetic average of the two metrics, which have been calculated previously. So, $\operatorname{sim}_{\mathrm{a}_{1}, \mathrm{a}_{2}}=0.88, \operatorname{sim}_{\mathrm{a}_{1}, \mathrm{a}_{3}}$ $\operatorname{sim}_{\mathrm{a}_{1}, \mathrm{a}_{3}}=0.64$ and $\operatorname{sim}_{\mathrm{a}_{1}, \mathrm{a}_{4}}=0.6$.

After that, it follows the calculation of the prediction for the satisfaction value for each LO, to the active learner. From our example, the list of recommendations in this step contains LOs $\mathrm{c}_{5}$ and $\mathrm{c}_{6} \cdot \mathrm{p}_{\mathrm{a}_{1}, \mathrm{c}_{5}}=4+\frac{((3-3) * 0.88)+((5-3.67) * 0.64)+((5-3.75) * 0.6)}{(0.88+0.64+0.6)}$ 
$=4.75$ and $\mathrm{p}_{\mathrm{a}_{1}, \mathrm{c}_{6}}=4.08$. Although it is not necessary to calculate the value for $\mathrm{c}_{3}$, its value would be $\mathrm{p}_{\mathrm{a}_{1}, \mathrm{c}_{3}}=4$ (satisfaction level assigned by the teacher).

Finally, the resulting list of recommendations for learner $\mathrm{a}_{1}$ shows LOs $\mathrm{c}_{5}$ and $\mathrm{c}_{6}$, by this order, with the predict value for the satisfaction level of 4.75 and 4.08 , respectively.

\section{Experimental Procedure}

\subsection{System Implementation}

Based on the requirements defined previously, we develop a prototype system to support the extended content manager and to implement the hybrid RS. It was implemented as a module in Moodle version 2.2.1, using its technology platform, PHP 5.3.8, MySql 3.4.9 and Apache 2.2.21 web server.

After login, using their Moodle system credentials, learners can select one recommendation activity that was created by the teacher. Main implemented functionalities so far, for learners, include creating, importing and updating LOs in the content management system, creating or updating profiles (see Fig. 4), accessing LOs and asking for a new list of recommendations (see Fig. 6). After completing one LO, learners should edit its recommendation and should define the time spent and satisfaction level associated with that LO (see Fig. 5).

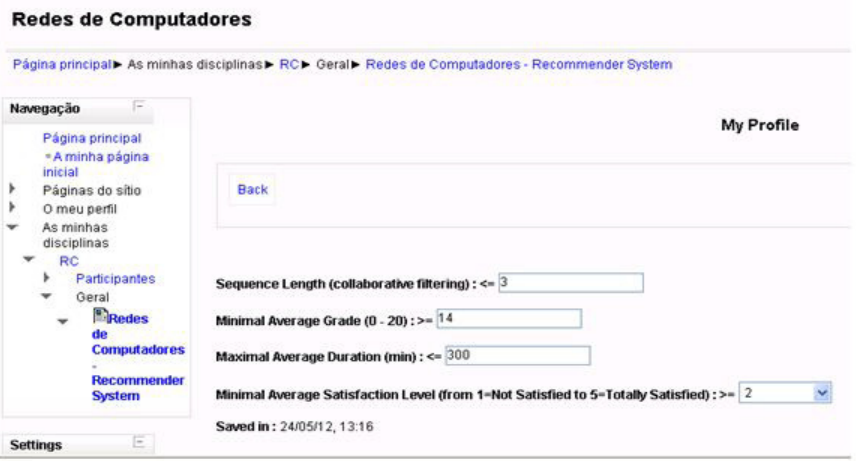

Fig. 4. Profile panel

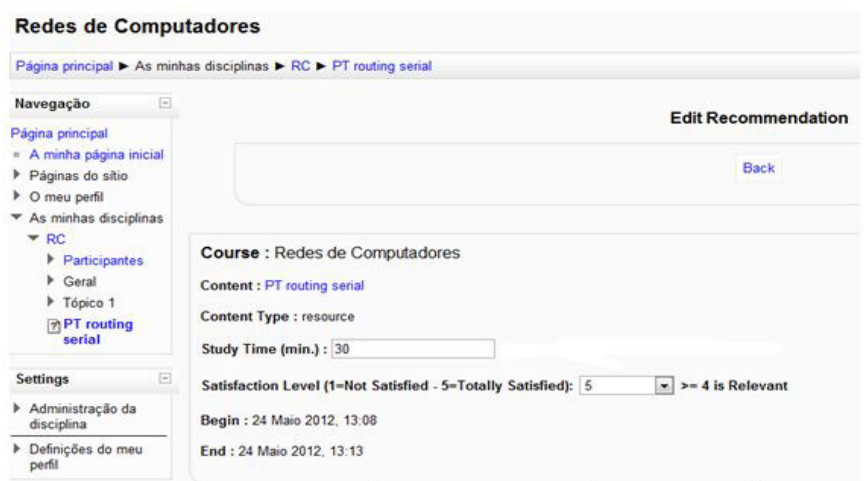

Fig. 5. Edit recommendation panel 


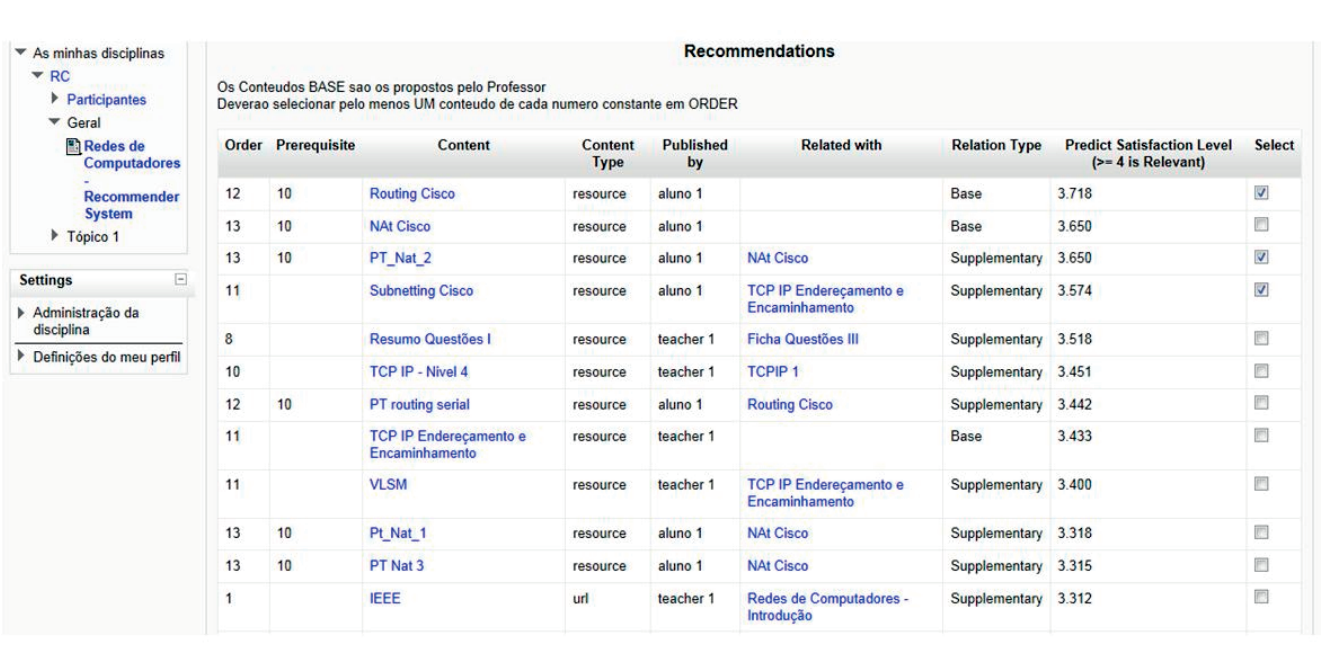

Fig. 6. List of recommendations panel

\subsection{Experimentation with the System}

The experiment was carried out in the courseware management system of a high school. Thirty two learners from the first year enrolled in a Computer Networks course have participated in this experiment during almost two months. In this period, $57 \mathrm{LOs}$ from 19 topics were added (maximum LOs per topic was 7 and minimum was 1), 40 with one prerequisite topic and 17 had no prerequisites. Nineteen LOs were classified as base (main LO from each topic) and the rest (38) as supplementary. Fifteen LOs were published by other learners and the rest (42) by teacher. The average to proposed default values to satisfaction level and to study time were, respectively, 3.73 (from a scale of $1-5$ ) and 80.5 minutes (a minimum of 5 and a maximum of 600 minutes, with a standard deviation of 93.9).

During these two months all class learners only had our proposed hybrid RS as support for their study, in addition to formal learning. They selected $595 \mathrm{LOs}$ in the 141 times that they asked for one next recommendation (an average of 4.2 LOs per each recommendation and an average of 18.6 LOs selected per learner). To these 141 recommendations, 49 had only one selected LO and 18 had 2 LOs. Only 13 of the 32 learners have selected LOs from all topics.

From all 595 selected LOs, only 156 selections are associated to a valid learner profile. Cold start selections had covered a large percentage (83.4\%, 496 in 595). From these 156 selections, phase 2 (social filtering) reduced the length recommendations list in 134 situations, and phase 3 (collaborative filtering) reduced its length in 56 situations. For each recommendations list we obtained an average number of 15.9 LOs, so our system had presented a sum of 2242 LOs to learners. From these, the average number of LOs classified as relevant (with a prediction value for satisfaction level greater than 
or equal to 4) was less than (47\%) the irrelevant ones $(53 \%)$. However, preference was placed on the relevant ones, with 60.5 per cent of selections.

As already mentioned, each learner has selected an average of 18.6 LOs. All learners have adopted different sequences of LOs, so at the end we had got 32 distinct sequences.

To test the accuracy of the recommendations, we use the Mean Absolute ErrorMAE (Herlocker et al., 2004) which determines the difference between the predicted satisfaction level and the real satisfaction level from the learner. The formula is given as follows:

$$
\text { MAE }=\frac{\sum_{i=1}^{N}\left|p_{i}-r_{i}\right|}{N}
$$

where:

$\mathrm{p}_{\mathrm{i}}$ is the predicted satisfaction level for LO I;

$r_{i}$ is the learner given satisfaction level for LO $i$ and

$\mathrm{N}$ is the total number of the pair satisfaction level $\mathrm{p}_{\mathrm{i}}$ and $\mathrm{r}_{\mathrm{i}}$.

When this data was exported, 532 LOs had already their real satisfaction level defined by learners, including 85 situations of non-cold-start. Considering the first group with all 595 selected LOs we obtain an MAE value of 0.79 . Just with non-cold-start recommendations this value is 0.43 . The evolution of these metrics is shown in Fig. 7 and Fig. 8.

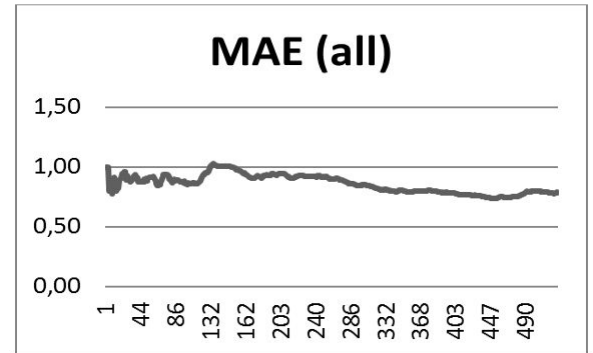

Figure 7 - Evolution of MAE (all recommendations)

Fig. 7. Evolution of MAE (all recommendations)

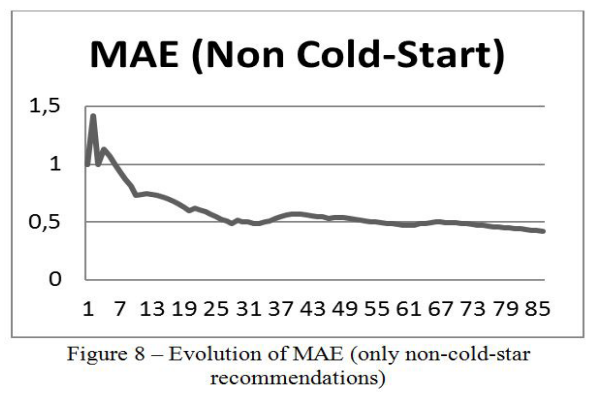

Fig. 8. Evolution of MAE (only non-cold-start recommendations)

Although students had completed 532 LOs, only 285 had any valid value in the study time parameter.

\subsection{Validation}

At the end of our experiment we invited students to evaluate our hybrid RS and answer an anonymous survey about the usability and usefulness of this system. We asked 11 questions (see Table 2), 6 of them requiring an answer on the Likert scale from 1 
(very negative) to 5 (very positive) and 4 requiring "Yes" or "No" as an answer. The last question required the learners to order a list of criteria, accordingly to their relevance in supporting the decision of choosing a LO.

Table 2. Survey questions

\begin{tabular}{|l|c|}
\hline \multicolumn{1}{|c|}{ Questions } & $\begin{array}{c}\text { Answer } \\
\text { Type }\end{array}$ \\
\hline $\begin{array}{l}\text { 1. Is it important that a student can publish new LOs available to colleagues, as } \\
\text { teacher does? }\end{array}$ & Likert 1-5 \\
\hline 2. Do you consider relevant that LOs have prerequisites? & Likert 1-5 \\
\hline $\begin{array}{l}\text { 3. Do you consider relevant to indicate the satisfaction level and study time of the } \\
\text { LOs after they have been studied? }\end{array}$ & Likert 1-5 \\
\hline $\begin{array}{l}\text { 4. Do you consider relevant that students have a profile to adjust their recommen- } \\
\text { dation strategy? }\end{array}$ & Likert 1-5 \\
\hline \begin{tabular}{l} 
5. How do you consider the ease of use of the recommendation system? \\
\hline $\begin{array}{l}\text { 6. Do you consider this system can help you to select LOs when there is a great } \\
\text { number of LOs (more than 300)? }\end{array}$
\end{tabular} Likert 1-5 \\
\hline \begin{tabular}{l} 
7. Haven't you chosen some LO because it has been published by a student? \\
\hline $\begin{array}{l}\text { 8. When selecting any LO, do you consider the prediction provided by the recom- } \\
\text { mendation system? }\end{array}$
\end{tabular} & Yes/ No \\
\hline $\begin{array}{l}\text { 9. When selecting any LO, do you consider the study time indicated by the rec- } \\
\text { ommendation system? }\end{array}$ & Yes/ No \\
\hline $\begin{array}{l}\text { 10. Did you understand that the values assigned to the satisfaction level and to } \\
\text { study time will influence the next recommendation of other students? }\end{array}$ & Yes/ No \\
\hline $\begin{array}{l}\text { 11. Sort by degree of importance the following criteria, used to select the LOs (a. } \\
\text { Predict satisfaction level; b. New LO; c. Type of Relationship; d. Number of } \\
\text { selections; e. Average of satisfaction level; f. Average of study time; g. Default } \\
\text { study time) }\end{array}$ & Order \\
\hline
\end{tabular}

The results of this survey show that 91 per cent of the learners considered it important to publish LOs, as teachers usually do. Half of learners pointed out that the existence of prerequisites matter. 77 per cent of learners gave importance to the possibility of indicating their satisfaction level and their study time, after they had studied the LOs. And although, only 26 per cent of the LOs were filtered accordingly to the values on the learners' profiles, 71 per cent of the studied population valorised profile customizations. Furthermore, 62 per cent of learners thought that this type of system can help to choose the more adequate LO, especially when there is a great repository. Nevertheless, 77 per cent of the population felt that this system was not easy to use.

The results of "Yes/No questions" group show that 59 per cent of the learners did not consider the publisher origin (teacher or student). When selections were made, 68 per cent considered the predicted satisfaction level, but only 27 per cent considered the amount of study time. 
It was important to understand that, on this system, values that characterized each LO experience, such as satisfaction level and time of study, will influence the next recommendation of other students. This idea was well understood by 73 per cent of learners.

The most important criterion (from the 8 suggested), was the prediction of the satisfaction level, recognized by 44 per cent of learners. Then, according to 33 per cent of learners, the second most important criterion was the kind of relationship (base, supplementary). The third was the default time of study indicated by the teacher, with 17 per cent of preferences. The last criterion, which was considered to be important, chosen by 6 per cent of learners, was the fact of a determined LO being new.

\subsection{Discussion}

The results of the analysis to our survey answers and to the data obtained from our experimentation show that participation of students, with the publication of new LOs, selection of LOs based on the prediction of satisfaction and the LO's assessment are the most positive and relevant ideas in our proposal.

All the population, consisting in 32 learners, has experimented unique learning experiences, representing 32 different learning paths in a Higher Education formal course, plus the traditional contact hours of learning with a teacher.

Analysis of MAE values shows us that the prediction value based on collaborative filtering is closer to the real value that each student assigns to the LO, confirming the interest of using this solution in supporting the decision of learner.

Although learners have referred that system's objectives were well understood, they didn't consider that the system was easy to use. Because we had no historic, we got many cold-start selections. Both factors can explain the low rate of selections with a valid learner profile $(26.22 \%)$.

\section{Conclusions and Future Work}

In this paper, we describe one LMS with some extra functionality not usually available in traditional ones like Moodle. We enable learners to add additional LOs. We also propose relationships between LOs with different semantic meanings. The access to these new LOs, submitted by learners, needs teacher approval, since we are in a formal course learning setting. We defend that these LOs might be available for several years and be used for future learners of the same courses, which is very different from traditional approaches where course LOs are published to be accessible during just one semester or one academic year. This will enable the system to have more LOs for learners to choose from, and analyses all previous learners' interactions with the system. This analysis is the basis for our hybrid recommender strategy, which will permit recommending suitable LOs to learners. We also believe that this extended system, will increase learning motivation without mischaracterizing the current formal learning model. 
In a system with a wide range of LOs, it is important to have some support to select the most suitable LOs for each learner. We want to enhance the suitability of their choices to their interests. So we propose a model based on a hybrid recommendation strategy that considers profile information (study time, sequencing and learner grade and satisfaction level). These four fields do not form a completed or unique solution, but rather a custom solution. There will be, of course, other criteria that may be included in the recommendation strategy, such as LO's difficulty level or its validity.

One relevant formulation for the recommendation strategy is the one presented for the calculation of the similarity between learners. It reflects the interests of the student (profile) in the calculation of grade-similarity metric (greater for learners with grades greater than or equal to that defined in profile) and in the calculation of sequencingsimilarity (where the presence of the same LOs and their order of selection will be valorised for the latest LOs that were chosen by active learner).

To make an experimental evaluation, we developed and used a prototype in a real higher education course. Our experimentation's results indicate that this solution can contribute to create different sequencing learning activities and unique experiences of learning. It was also found that the prediction accuracy is higher when the system generates recommendations based on collaborative filtering for learners with a valid profile, which indicates that our hybrid strategy of recommendations allows to make decisions that suit the learner's needs.

As our focus in this work was a personalization of learner's learning path and also adding diversity, we were able to reach to some important conclusions in this field. In particular, the experiment shows that our techniques are able to reflect learners' interests.

However, the design of a friendly-use system emerges as both crucial and complex task, required for the success of this kind of solutions.

In future works, we will explore the relevance of publishing by learners in their learning process, as well as comparing the influence of the different metrics used to calculate learners' similarities. Before the next experimental essays it is necessary to improve our system, seeking for a better usability. We also want to do an experimental evaluation with learners enrolled in other courses, not directly related with computer science.

For the near future we also believe that more important research must be done, focusing on the contributions of these kinds of solutions to the success of learners.

\section{Acknowledgement}

The authors are pleased to acknowledge financial support from Fundação para a Ciência e a Tecnologia and FEDER/COMPETE (grant PEst-C/EGE/UI4007/2011). 


\section{References}

Breese, J. S.; Heckerman, D.; Kadie, C. "Empirical Analysis of Predictive Algorithm for Collaborative Filtering." In Proceedings of the Fourteenth Conference on Uncertainty in Artificial Intelligence (eds G.F. Cooper \& S. Moral). San Francisco CA: Morgan Kaufmann Publishers Inc., 1998. p. 43-52.

Drachsler, H.; Hummel, H. G. K.; Koper, R. "Personal Recommender Systems for Learners in Lifelong Learning: Requirements, Techniques and Model." International Journal of Learning Technology., 2008, 3(4): 404-423.

Drachsler, H.; Hummel, H. G. K.; Koper, R. "Identifying the Goal, User Model and Conditions of Recommender Systems for Formal and Informal Learning." Journal of Digital Information, 2009, 10(2): 4-24.

Gutiérrez, S.; Pardo, B. "Sequencing in webbased education: Approaches, standards and future trends." In Evolution of Teaching and Learning Paradigms in Intelligent Environment (eds L. Jain, R. Tedman, D. Tedman \& J. Kacprzyk). Berlin: Springer, 2007. p. 83-117.

Herlocker, J. L. et al. "Evaluating Collaborative Filtering Recommender Systems." $A C M$ Transactions on Information Systems, 2004. 22(1): 5-53.

Iglesias, A. et al. Learning Content Sequencing in an Educational Environment According to Student Needs. In Algorithmic Learning Theory (eds S. Ben-David, J. Case \& A. Maruoka). Berlin: Springer, 2004. p. 454463.

Liang, G.; Weining, K.; Junzhou, L. "Courseware Recommendation in E-Learning System." In Proceedings of the $5^{\text {th }}$ International Conference on Advances in Web Based Learning-ICWL 2006 (eds W. Liu, Q. Li \& R.W.H. Lau). Berlin: Springer, 2006. p. 10-24.

Koper, E. J. R. "Increasing Learner Retention in a Simulated Learning Network Using
Indirect Social Interaction." Journal of Artificial Societies and Social Simulation, 2005, 8(2): 1-19.

Manouselis, N.; Vuorikari, R.; Van Assche, F. "Simulated Analysis of MAUT Collaborative Filtering for Learning Object Recommendation." In Proceedings of the $1^{\text {st }}$ Workshop on Social Information Retrieval for Technology-Enhanced Learning \& Exchange. Crete, 2007. p. 27-35.

Manouselis, N.; Vuorikari, R.; Van Assche, F. "Collaborative Recommendation of e-learning Resources: an Experimental Investigation." Journal of Computer Assisted Learning, 2010, 26(4): 227-242.

Manouselis, N. et al. Recommender Systems in Technology Enhanced Learning. In Recommender Systems Handbook (eds F. Ricci, L. Rokach, B. Shapira \& P.B. Kantor). US: Springer, 2011. p. 387-415.

Melville, P.; Mooney, R. J.; Nagarajan, R. Content-boosted Collaborative Filtering for Improved Recommendations. In Eighteenth National Conference on Artificial intelligence (eds R. Dechter, M. Kearns \& R. Sutton). Menlo Park CA: American Association for Artificial Intelligence, 2002. p. 187-192.

Pazzani, M. J. "A Framework for Collaborative, Content-based and Demographic Filtering." Artificial Intelligence Review, 1999, 13(5): 393-408.

Rafaeli, S. et al. "QSIA - a Web-based Environment for Learning, Assessing and Knowledge Sharing in Communities." Computers \& Education, 2004, 43(3): 273289.

Soboroff, I.; Nicholas, C.; Nicholas, C. K. "Combining Content and Collaboration in Text Filtering." In Proceedings of the IJCAI'99 Workshop on Machine Learning for Information Filtering, Stockholm, 1999. p. 86-91. 
Tang, T.; McCalla, G. "Smart Recommendation for an Evolving E-Learning System: Architecture and Experiment." International Journal on E-Learning, 2005, 4(1): 105-129.

Zapata, A. et al. A Hybrid Recommender Method for Learning Objects. IJCA Proceedings on Design and Evaluation of Digital Content for Education (DEDCE), 2011, (1): 1-7.
Walker, A. "Collaborative Information Filtering: a Review and an Educational Application." International Journal of Artificial Intelligence in Education, 2004, 14(1): 3-28.

\title{
MIŠRAUS REKOMENDAVIMO STRATEGIJA MOKYMUISI: EKSPERIMENTINIS TYRIMAS
}

\author{
Filipe Montez Coelho Madeira \\ Vadybos ir technologijų mokykla, Santaremo politechnikos institutas, Portugalija, \\ filipe.madeira@esg.ipsantarem.pt \\ Salvador Luís de Bethencourt Pinto de Abreu \\ Evoros universitetas, Portugalija, spa@di.uevora.pt \\ Rui Filipe Cerqueira Quaresma \\ Evoros universitetas, Portugalija, quaresma@uevora.pt
}

Santrauka. Didejantis technologiniu inovaciju, eksperimentu bei tyrimu kiekis kuria scenarijus, kur laikas ir erdve igyja naujas reikšmes. Tinkamu mokymosi resursu identifikavimas bei išskyrimas iš gausybès potencialiu variantu pasitelkiant interneta, tapo itin aktualia paslanga. Socialiniai tinklai ir debesu kompiuterijos sprendimai yra pastaruju laiku inovacijos, užtikrinančios lengvesne prieiga prie resursu (skirtingose laiko ir erdves dimensijose, pasitelkiant daugybę terminalu). Nuotolinis mokymas igauna vis didesnę reikšme (netgi naudojamas kaip auditorinio mokymo pakaitalas).

Žvelgti i mokymąsi per besimokančiojo prizme, pateikiant ji kaip centrine proceso aši, yra viena iš naujuju tendenciju mokymosi doktrinoje. Šis požiüris ypatingas tuo, jog besimokantysis yra laikomas žiniu generatoriumi, o pačios žinios neatsiranda vien dèl trečiuju šaliu pateikiamos informacijos. Konstruktyvistinis mokymo modelis teigia, jog žinios atsiranda kaip socialiniu konstruktu squeikos rezultatas, kolaboratyvioje aplinkoje, dalyvaujant skirtingiems mokymosi subjektams. Ši aplinka reikalauja nauju technologiju, mokymosi metodu bei proceso paramos ịrankiu. Ivairüs besimokantieji su skirtingomis charakteristikomis, igüdžiais, pajegumu bei tikslais siekia tinkamiausiu san mokymosi veiklu bei resursu. Diferencijuotas turinys, adaptyvus mokymosi nuoseklumas yra keli is reikalavimu siekiant igyvendinti anksciau minetas mokymosi metodikas.

Pagrindinis šios publikacijos tikslas - atrasti büdus, padedančius gerinti mokymo kokybe formaliojo aukštojo mokslo kontekste. Šiame straipsnyje pristatome į besimokantiji orientuota modeli, su personaliai pritaikytomis rekomendacijomis bei mokymosi veiklomis. Mes teigiame, 
jog besimokantieji gali skelbti naudingo turinio medžiaga bei ja vertinti. Šie turiniai gali büti susieti, siekiant padèti besimokantiesiems informacijos atrinkimo procese. Müsu sistema numatys mokymosi aktyvumo rezultatus remdamasi besimokančiojo profiliu, hibridine rekomendaciju strategija bei kombinuojant salyginio ir kolaboratyvinio filtravimo metodus. Šie iverčiai padès besimokantiesiems pasirinkti tinkamiausias mokymosi veiklas. Mes teigiame, jog besimokančiuju panašumai gali büti nustatomi remiantis ịvertinimu rezultatais bei mokymosi istorija. Straipsnyje pristatomas motyvacines mokymosi metodo tinkamumo prielaidos bei koncepcines ir praktinès jzžvalgos. Taip pat pristatome sistemos architektüros bei dizaino koncepcijas. Müsu pasiülytas modelis yra realizuotas pasitelkiant Moodle studiju valdymo sistema. Realüs formaliuju studiju eksperimentiniai kursai buvo vykdomi du menesius aukštojo mokslo institucijoje. Eksperimento rezultatai parodè, jog panašiu sistemu vystymas padeda studijuojantiesiems diversifikuoti mokymosi kelius bei patirtis, padidina naudinga bendradarbiavima, padeda geriau priimti sprendimus. Nepaisant to, šiems sprendimams ịvaldyti reikia praktikos bei tinkamo dizaino realizavimo, siekiant palengvinti ju pritaikomuma.

Reikšminiai žodžiai: rekomendavimo strategija, individualizuoto rekomendavimo sistemos, bendradarbiavimo filtravimas, formalus mokymasis bendradarbiaujant, mokymosi nuoseklumas, besimokančiojo profilis, technologijomis paremtas mokymasis. 